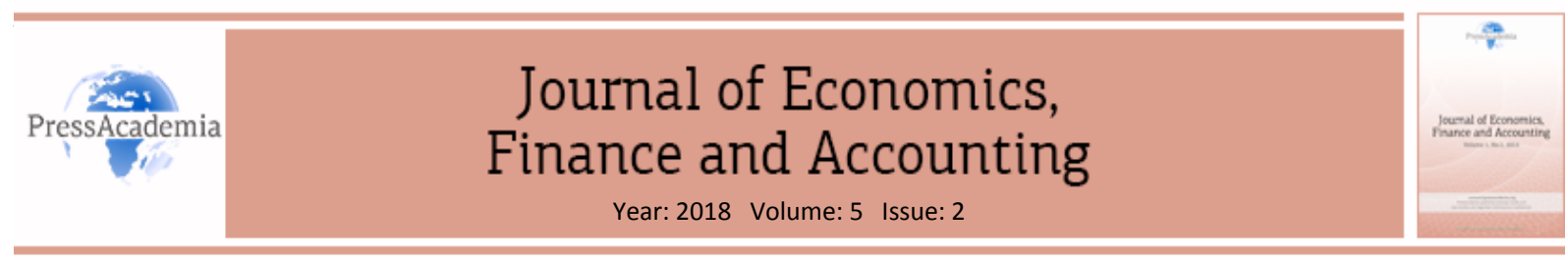

\title{
THE EFFECTS OF OWNERSHIP STRUCTURE ON FINANCIAL PERFORMANCE OF ENTERPRISES IN THE LIGHT OF ACCOUNTING BASED PERFORMANCE INDICATORS: A RESEARCH ON THE FIRMS TRADED ON THE BIST INDUSTRIAL INDEX
}

\author{
DOI: 10.17261/Pressacademia.2018.824 \\ JEFA- V.5-ISS.2-2018(4)-p.184-203
}

\author{
Gokhan Ozer ${ }^{1}$, Ali Korhan Ozen ${ }^{2}$ \\ ${ }^{1}$ Gebze Technical University, Gebze Technical University Faculty of Business Administration 41400 Gebze, Kocaeli, Turkey. \\ gokozerhan@gmail.com, ORCID: 0000-0002-3255-998X \\ ${ }^{2}$ Gebze Technical University, Gebze Technical University Faculty of Business Administration 41400 Gebze, Kocaeli, Turkey. \\ akorhanozen@gmail.com, ORCID:0000-0002-4995-6914
}

\section{To cite this document}

Ozer, G., Ozen, A. K. (2018). The effects of ownership structure on financial performance of enterprises in the light of accounting based performance indicators: a research on the firms traded on the BIST industrial index. Journal of Economics, Finance and Accounting (JEFA), V.5(2), p.184-203.

Permemant link to this document: $\mathrm{http}: / /$ doi.org/10.17261/Pressacademia.2018.824

Copyright: Published by PressAcademia and limited licenced re-use rights only.

\section{ABSTRACT}

Purpose-The purpose of this study is to determine the effects of the ownership structure in the enterprises traded on BIST on their financial performance in the light of accounting based performance indicators.

Methodology-It has been benefited from the data of 112 enterprises. Models created to examine the effects of the ownership structure on the financial performance of the enterprise were subjected to panel data analysis by Eviews 8 programme.

Findings-It was determined that the free float rate and the corporate investor ratio have a statistically negative significant effect on the return on assets, the foreign share has a positive significant effect, the corporate investor share has a negatively significant effect and the firm size has a statistically positive effect on the return on equity.

Conclusion- It is found that the ownership structure of firms has statistically significant effect on ROA and ROE which are dimensions of financial performance.

Keywords: Ownership structure, financial performance, firm size, panel data analysis, Istanbul Stock Exchange (BIST) JEL Codes: C33, G32, M41

\section{INTRODUCTION}

The conflicts of interest between the enterprise owners, managers and other shareholders and the conflicts of interest between the individuals having the authority to control the enterprise and the shareholders following the enterprise from the outside constitute the center of the corporate governance literature. Although some similarities can be found in the ownership of the enterprises, serious differences can also be observed. These differences can affect the financial performance of the enterprise and these impacts arising from the differences affect the decision on formation of the ownership structure.

The notion of ownership means to have the right to be able to make savings and to transact for the existing asset due to having the right to use the asset. The notion of the ownership concentration refers to the control of a high percentage of the existing shares belonging to the enterprise by a certain individual or individuals. In parallel with the gradually growing enterprise structures, the increase of the shareholders has led to some changes which are also continued today in the existing ownership structures. The ownership structure, which is one of the variables affecting financial performance of the enterprises, is discussed in two different ways in the literature.

The first one focuses on the partnership concentration and is determined in accordance with the percentage of the shares owned by the shareholders, and the second one is formed in accordance with the partnership composition. The partnership composition is taken into consideration in regard to the individual and/or corporate partners established the partnership in the enterprise and a classification is made in accordance with that criterion. The partnership composition is analyzed in different forms such as managerial ownership, family ownership, corporate investor ownership, state ownership and 
foreign ownership which is defined by the foreign ownership structure. From this point of view, the controlling shareholder will pressure on the management at the degree of concentration in order to avoid the risks in accordance with the degree of ownership concentration in the enterprise (Fettahoğlu and Okuyan, 2009). Up to the present, reflections of the diversities regarding the ownership structure on the financial performance in an enterprise have been subjected to analyses in different periods of time and within the scope of many different studies in the literature through different variables in terms of the countries with different levels of development and economy.

The notion of performance generally means that realization of the aims previously determined in different ways is subjected to analysis. If it is necessary to explain the notion of performance from the point of the enterprises, we can define it as the sum of efforts which indicate the state of realization of the aims and targets. In our day, importance of the reference to the notion of performance shown by the enterprises has increased by maximizing the value to be obtained from the shares and providing the profitability which are the main aims of the enterprises. The main aim of the enterprises on the financial performance is to bring their profitability and current assets to the maximum level for their partners and shareholders.

The aim of this study is to examine the relationship between the ownership structure and the financial performance of the enterprises, which are traded on the BIST industrial index and continue their activities uninterruptedly between the years of 2006 and 2014, through the accounting based financial performance indicators. Thus, it is aimed to reveal the effects of the characteristics regarding the ownership structure of the enterprises on their performance. Analysis of this effect based on the relevant performance criteria will reveal whether there is an effect of the ownership structure on determination of the financial performance of the enterprises. If the aims of this study are to be expressed in detail, the ownership structure defines the individuals who represent the business capital and determination of the size of the shares (izciler, 2014). The share of the largest partner which defines the number of individuals having the share majority, in other words, the condition in which the shares are collected by certain individuals and therefore the individuals or institutions having the control and management of the enterprise, the number of partners holding the majority (number of the partners holding more than $10 \%$ of share), the foreign share, the free float rate and the corporate investor ratio are used as the variables of the ownership structure. Though these variables used are the factors which form the ownership structure in the enterprises, it is necessary to determine the extent and intensity of the efficiency of these factors on the performance.

The study consists of four chapters. Following the introduction, the second chapter includes the studies which examine the effect of the ownership structure in the enterprises on the performance. The main purpose of the study, the structure of the sample, the conceptual model, the constraints of the study, the data set, the independent and dependent variables used, the hypotheses, statistical results on the study and interpretations of the results are discussed in the third chapter. In the conclusion which is the fourth chapter, information regarding the general discussion of the study is provided.

\section{LITERATURE REVIEW}

\subsection{Ownership Structure and Financial Performance of the Enterprises}

The view in which the capital owners have expanded to a wide basis in the enterprises (in other words, having a low intensity partnership structure) and the enterprise is being controlled by the managers has been possessed in the corporate finance for a long time. This expression mentioned as "Concentrated Ownership" in the literature means that the ownership has concentrated on a specific group of shareholders. As the level of this concentration increases, in other words, as the level of ownership of a shareholder increases, such ownership structures are mentioned as the concentrated ownership or partnership structure. Otherwise, the structure is defined as the widely held ownership as it spreads more to the base. The starting point for this view is Berle and Means' work "Modern Corporation and Private Property" published in 1933 and benefited by many authors. In this work, Berle and Means noted that the enterprises in the USA which have a capital structure spread on a wide basis are prevalent and remarked that the ownership of the capital is distributed among the small shareholders and the control is concentrated in the hands of the senior managers. Therefore, it is thought that this work caused the formation of a literature within a supervisory framework (Demsetz and Lehn, 1985; La Porta, Lopezde-Silanes and Shleifer, 1999). After this work, the conflicts of interest between the managers and the shareholders are being intensively studied by the researchers who try to understand the nature of the firms (Demsetz and Lehn, 1985; Jensen and Meckling, 1976). Jensen and Meckling (1976) argued that the managers who are the shareholders at a low level cannot maximize the shareholder wealth, and the reason is that the managers tend to use additional appropriations.

Nevertheless, Demsetz and Lehn (1985) argued that the shareholders have both advantages and disadvantages from their intensity in the ownership structure. For the authors, the benefits to be obtained by the owners from reducing the share of ownership create a disadvantage for a greater intensity. According to this, the owners can direct their energy and time to the works in which the benefits remain completely for themselves. The cost of avoiding from ownership will most likely be a lower enterprise performance, and its results will be shared by all the shareholders at the rate of their shares. 
La Porta et al. (1999) summarized the studies provided the evidences of increased managerial ownership by the end of the 1990s. The authors found in their samples that the $36 \%$ of the large enterprises are in the low intensity, $30 \%$ of them are controlled by a family or individuals, $18 \%$ of them are controlled by the state, $5 \%$ of them are controlled by a low intensity financial institution and $5 \%$ of them are controlled by a low intensity enterprise. For smaller enterprises, the percentage of the companies controlled by the family has increased in 53\%. For the authors, these studies indicate that the large enterprises in many countries have large shareholders and that these shareholders also take an active role in corporate governance.

The impact of the ownership structure on the firm performance has also been examined theoretically and empirically. Berle and Means (1933) argued that the ownership concentration should affect the firm value positively as it reduces the conflict of interest between the shareholders and the managers. The relationship between the concentrated ownership and the firm performance and the relationship between the strengthening mechanisms for control and the firm performance are prominent among the studies which examine the relationships between the ownership and the performance. A positive (McConnell and Servaes, 1990; Morck, Shleifer and Vishny, 1988) or negative (Villalonga and Amit, 2006) relationship is predicted based on the effects of alignment and entrenchment of the relationship theories between the concentrated ownership (partnership) and the firm performance. Therefore, the managerial ownership with a low shareholding level increases the firm value as the interests find a common ground. However, the managerial ownership with a high shareholding level causes a decrease in the firm value and more conflicts of interest due to the reinforcement effect.

However, statistically insignificant relationships were determined between the ownership and the performance. Demsetz and Lehn (1985), Demsetz and Villalonga (2001), Himmelberg, Hubbard and Palia (1999) have obtained empirical results which state the ownership concentration is an endogenous result of the shareholders' decisions made in order to maximize their own profit. Thus, they argued that the ownership concentration has no effect on the firm value. For Demsetz and Villalonga (2001), coefficient of the Tobin $Q$ variable is negative in the ownership equations, and the relevant negative effect is more than the ownership concentration in the internal ownership.

For Demsetz and Lehn (1985), three of the factors which affect the ownership structure should be examined. These factors are the value-maximizing size of the firm, the profit potential from exercising more effective control, and systematic regulation made in accordance with the scope and effect of the decisions made by the shareholders. McConnell and Servaes (1995) assumed that the ownership is more important in the high growth firms than the low growth firms, and they stated that the relationship between the ownership structure and the firm performance varies by the low or high growth of the enterprises.

Furthermore, external block ownership such as managerial share ownership is one of the structures in the literature. The managerial ownership is defined as the ratio of shares owned by managers and other members of the board of directors (Brailsford, Oliver and Pua, 2002). Morck et al. (1988) determined the average level of the managerial share ownership as $10.60 \%$; McConnell and Servaes (1990) determined the average level of the managerial share ownership as $11.84 \%$, and Brailsford et al. (2002) determined the average level of the managerial share ownership as $10.65 \%$.

However, Brailsford et al. (2002) defined the external block ownership as the percentage of shares owned by the large shareholders. This percentage indicates the ownership ratio of the five largest shareholders, and the ownership ratio of the largest 2 and 20 shareholders has been used as sensitivity analyses and control variables. The authors used the data of the largest 2, 5 and 20 external shareholders for the external block shareholder representative.

The family ownership is also examined in the literature on ownership. This type of ownership structure can be seen in the enterprises in which the ownership percentage of the family members or the family is high. For Morck, Stangeland and Yeung (1998) and Villalonga and Amit (2006), the family ownership reduces the usual conflict between the owner and the manager. Therefore, it is expected that the agency theory will have a positive effect on the firm performance of the family ownership. However, Morck et al. (1998) found a negative effect between these two variables. On the other hand, Villalonga and Amit (2006) found an evidence that the positive effect can only be seen when control and management come together through a certain form. For the authors, the effects of ownership are not clear as the previous studies could not separate the family ownership from the family control and the family management.

King and Santor (2008) argued that these non-common results obtained from the empirical studies on the family ownership and the firm performance are based on two reasons regarding determination and prediction of the model. The first one is based on the view that the relationship between the family ownership and the performance is not identified without separation of control and ownership from each other. While the family owners can follow the management, and become an active investor, they can also use the mechanisms such as the dual-class share structure or the pyramidal structures to strengthen the voting right. The presence of the dual-class shares is observed in case that there are two are more share classes with different rights to vote. On the other hand, the pyramidal ownership structures are observed in case that the blockholder (usually the family) controls the main company or holding. These mechanisms empowering the control cause a decrease in the level of alignment of the incentives of the controlling shareholders (the corporate shareholders) and the 
minority shareholders, increase the managerial consolidation and the risks of expropriation or asset and income transfer. For the authors, the second problem is the unobservable firm heterogeneity. The presence of unobservable effects of the ownership on the performance poses a problem for determination of the direction of causality. Therefore, the single equation models such as cross-sectional studies which disregard the firm heterogeneity will lead to prejudicial results.

\section{DATA AND METHODOLOGY}

\subsection{Aim of the Study}

The aim of this study is to examine how the diversified ownership structures of the firms affect the financial performance under the guidance of the accounting based performance criteria and to determine whether the ownership structures have an effect on the financial performance of the firms. The changes created by the percentaged differences in the share of the largest partner, the corporate investor ratio, the foreign share, the number of the majority shareholders and the free float rate on the return on assets and the return on equity will be analyzed in this study. The reason for selection of the industrial index and the service index is to be able to obtain clearer and real-like results in practice.

\subsection{Data Set and Sampling Used in the Study}

The firms in this study were selected from the enterprises traded on the Industrial Index (XUSIN) and listed on Borsa Istanbul (BIST). It has been paid attention to prefer the enterprises listed on the industrial index without making any sectoral distinction and to properly collect the nine-year (2006-2014) data of 112 enterprises. The main reason for collection of the data in 2006 and the following years is that the effects of the economic crisis observed around the world in 2008 on financial performance of the enterprises can be examined closely. Furthermore, it should be especially considered that data of the firms to be used in the relevant study do not include all firms located in Turkey and traded on Borsa Istanbul (BIST).

In the beginning of the study, all data of 147 enterprises traded on the industrial index between the years of 2006 and 2014 were included in the scope of the analysis. However, 35 enterprises in total were excluded from the analysis because they did not meet the data of the years in the study period. As a result, $1008(112 * 9)$ data in total were analyzed based on the 9year data of 112 enterprises. During the analysis, it was determined that the series were not stationary due to the unit root problem. The first and second-degree difference, square root and logarithmic transformations were made in order to ensure the stability of the series. As a result of these transformations, the number of observations has decreased. Due to this reason, 890 observations were analyzed in the industrial index.

The financial data of the enterprises analyzed were obtained in two different ways. The financial data of the enterprises in 2008 and the early periods included in the relevant index were acquired from the official website of the BIST (www.borsaistanbul.com). The data regarding to 2009 and later were acquired with the public information published in the official website of the BIST (www.borsaistanbul.com), the official website of the Public Disclosure Platform (KAP) (www.kap.gov.tr), the official website of the Central Registry Agency (MKK) (www.mkk.com.tr), the official website of Finnet 2000 Plus (www.finnet.com.tr) and the official website of the enterprises through the use of the programs called Finnet Excel Add-in and Finnet Stock Expert.

\subsection{Variables Used in the Study}

Dependent, independent and control variables were primarily preferred in the study. In determination of the variables, it has been started from the variables reached the most consensus on the literature. As the effects of the relevant variables on the financial performance in the enterprises were analyzed, performance determinants of the enterprises consist of the accounting based performance measurement techniques. The variables used in the study are classified under three titles as the ownership structure, the financial performance and the control variable. The independent variables used in the study are composed of the variables which represent the ownership structure. To increase the descriptive capacity of the model created considering the relevant variables, the control variable which is thought to be effective on financial performance of the enterprises has been included in the relevant models.

Dependent variables of the relevant study are the return on assets (ROA) and the return on equity (ROE) shown in the table 3. The independent variables are respectively the share of the largest partner (EBOP), the free float rate (HAO), the number of the partners (ORTAK), the foreign share (YABP), the corporate investor ratio (KURY) and these variables are shown in the Table 1. The control variable firm size (VALOG) which is thought to be effective on the financial performance and it is shown Table 2 . 
Table 1: Independent Variables of the Model (Ownership Structure)

\begin{tabular}{|l|l|l|l|l|}
\hline Variables & Description & Symbol & Variable Calculations & Author \\
\hline $\begin{array}{l}\text { Structure } \\
\text { Largest Partner }\end{array}$ & $\begin{array}{l}\text { Share of the } \\
\text { Free Float Rate }\end{array}$ & HAO & $\begin{array}{l}\text { Capital Amount of the Largest Partner / } \\
\text { Total Equity }\end{array}$ & $\begin{array}{l}\text { Bayrakdaroğlu (2010) } \\
\text { Oruç (2012) } \\
\text { Toraman and Okuyan } \\
\text { (2009) }\end{array}$ \\
\hline & $\begin{array}{l}\text { Number of the } \\
\text { Partners }\end{array}$ & ORTAK & $\begin{array}{l}\text { Number of the partners with more than } \\
10 \% \text { of the capital shares }\end{array}$ & $\begin{array}{l}\text { Bayrakdaroğlu (2010) } \\
\text { Zhang (1998) }\end{array}$ \\
\hline & Foreign Share & YABP & $\begin{array}{l}\text { Capital Share of the Foreign Partner / Total Topal (2015) } \\
\text { Equity }\end{array}$ & $\begin{array}{l}\text { Bayrakdaroğlu (2010) } \\
\text { Büyükmert (2015) } \\
\text { Li et al. (2009) }\end{array}$ \\
\hline & $\begin{array}{l}\text { Corporate } \\
\text { Investor Ratio }\end{array}$ & KURY & $\begin{array}{l}\text { Capital Share of the Corporate Investor / } \\
\text { Total Equity }\end{array}$ & $\begin{array}{l}\text { Kumar (2006) } \\
\text { Mirzaei (2012) } \\
\text { Pushner (1995) } \\
\text { Sayman (2012) }\end{array}$ \\
\hline
\end{tabular}

Table 2: Control Variable of the Model

\begin{tabular}{|l|l|l|l|l|}
\hline Variables & Description & Symbol & Variable Calculations & Author \\
\hline $\begin{array}{l}\text { Ownership } \\
\text { Structure }\end{array}$ & Firm Size & VALOG & Natural Logarithm of the Total Assets & $\begin{array}{l}\text { Deesomsak et al. (2004) } \\
\text { Friend and Lang (1988) } \\
\text { Huang and Song (2006) } \\
\text { Mehran, Taggart and } \\
\text { Yermack (1999) }\end{array}$ \\
\hline
\end{tabular}

Table 3: Dependent Variables of the Model (Financial Performance)

\begin{tabular}{|l|l|l|l|l|}
\hline Variables & Description & Symbol & Variable Calculations & Author \\
\hline Dependent & $\begin{array}{l}\text { Return on } \\
\text { Assets }\end{array}$ & ROA & ROA=Net Income / Total Assets & $\begin{array}{l}\text { Nazir and Afza (2009) } \\
\text { Singh and Pandey (2008) } \\
\text { ALShubiri (2011) }\end{array}$ \\
\hline & $\begin{array}{l}\text { Return on } \\
\text { Equity }\end{array}$ & ROE & ROE=Net Income / Equity & $\begin{array}{l}\text { Nazir and Afza (2009) } \\
\text { Singh and Pandey (2008) } \\
\text { ALShubiri (2011) }\end{array}$ \\
\hline
\end{tabular}

\subsubsection{Return on Assets (ROA)}

The return on assets is a ratio which determines how much profit an enterprise earned from its total assets and which is one of the most frequently used measures in determination of the enterprise performance (Kaufman and Watstein, 2008). The return on assets ratio indicates how efficient the enterprises use their total assets. This performance indicator is considered as a financial performance criterion in terms of the dependent variable in the relevant studies (Albayrak and Akbulut, 2008; Hall and Weiss 1967; Kandır, Karadeniz, Özmen and Önal, 2008; Külter and Demirgüneş 2007; Whittington, 1980).

The return on total assets is an indicator which measures the percentage of income earned by the enterprise from the investments made for its assets within a certain period. The enterprises make an effort to gain the maximum benefit from each investment made for their assets. The point to be emphasized is that what percentage of the investments is made by the equity and what percentage of the investments is made by the foreign resources (Akdogan and Boyacioglu, 2014).

When the return on total assets is calculated, the net income after tax is used on the basis of the total assets. This indicator consists of a combination of two different variables as the profit margin and the total assets turnover ratio. If the return on total assets is to be rearranged on this basis (Young and O'Byrne, 2001), the following equation is obtained:

The return on assets $=$ Net Income/Net Sales $x$ Net Sales/Net Assets

Therefore, the return on assets can be defined as a combination of the profit margin and the total assets turnover ratio. For Rakshit (2006), the indicator of the return on assets is a financial performance indicator which gives the best results, and all activities performed in the enterprise will eventually contribute to the return on assets. 
When the return on assets is calculated, the units in numerator and denominator of the relevant ratio may show an alteration. While income is considered as an activity term in some enterprises, the item of net income can be used in many enterprises. This variability can be also valid for the total assets in the denominator of the ratio. The assets owned by an enterprise can be defined as the total assets as well as the result obtained when we deduct the short-term debts from the total assets (Horngren, Foster and Datar, 1999). Different results may occur because different items can be used in the parts of numerator and denominator, and many changes can be seen on the financial structure of the enterprise in time (Saldanll, 2006). As the relevant ratio indicates the remaining amount after deduction of the net income, interests and taxes, the ratio may be low or high in accordance with the changes observed on the financial structure of the enterprises. Therefore, the use of the profit unit before tax and interest instead of the net profit unit in the numerator part of the formula in the profitability analyses to be made based on the enterprises with different financial structures may lead to a truer and more significant indicator for the result to be obtained (Akgüç, 1998).

\subsubsection{Return on Equity (ROE)}

Return on equity is also known as the return on shareholder's equity in the literature (Escalona, 2002; Rappaport, 1998). The return on equity is considered as an important ratio which indicates the relationship between the capital invested in the enterprise by the shareholders and the income earned. This ratio also shows how efficiently the enterprise is managing the capital invested by the shareholders. In addition that it indicates the return on equity invested in the enterprise by the shareholders, it is calculated by dividing the income after tax by the equity.

When the return on equity ratio is considered from the point of the return, in other words, the maximization of the capital invested by the shareholders, the return ratio provided by the equity capital for an entity within the body of the enterprise in the period is an important criterion for the shareholders as the main aim is to increase the enterprise value (Ercan and Ban, 2005).

The return on equity determines the extent to which the return earned from the equity invested in the enterprise by the shareholders changes in the relevant year. This indicator is considered as an accounting based performance criterion by reason of the fact that it is aimed the shareholders can earn profit (Cenger, 2006). The ratio of return on equity includes three main components as the profit margin, the asset turnover and the equity multiplier (Livingstone and Grossman, 2002). These three components are formulated as follows:

\section{Return on Equity $=$ Net Income/Net Sales $\times$ Net Sales/Assets $\times$ Assets/Equity}

Managers in the enterprises may lead to a manipulation in the return on equity making a change in the components of the above formula. From this point of view, it is also possible to establish a relationship between the return on equity and the return on assets through the leverage ratio as follows (Müslümov, 2005; Grant, 2003). The leverage ratio is calculated by dividing the total liabilities by the total assets.

$$
\text { Equity = Return on Assets/(1-Leverage Ratio) }
$$

Based on the relationship stated in the above formula, it can be said that a possible change in the equity results from the return on assets or the leverage ratio. An increase should be provided in the return on assets and the leverage ratio in order to obtain an increase in the return on equity.

Palepu, Healy and Bernard (2000) suggested that the net operating income after tax can be also added as an alternative in the formula used in calculation of the return on equity. On the other hand, Pavelkova and Knapkova (2003) argued that it is necessary to include the variables such as the interests paid, the sum of loans and bonds, external resources, other debts and the equity multiplier in the relevant formula. The return on equity indicator does not present any business profile which leads to an increase or a decrease in value for the shareholders of the enterprises. The main reason is that it is not possible to determine whether the relevant ratio generates a return more or less than the cost of equity invested in the enterprise by the shareholders. Therefore, it is not a criterion to be subjected to the relevant comparison. Though it gives the managers an idea on the present condition of the enterprise, it does not play a directing role especially in operational activities (Makelainen, 1999).

\subsubsection{Share of the Largest Partner (EBOP)}

This variable is a ratio used to determine what percentage of the total shares in the enterprise is owned by the person who is the principal shareholder of the enterprise. It is possible to have a decrease in number of the variables used to measure the return of the enterprise as the percentage of the shares owned by the largest shareholder has increased. The main reason of the relevant problem is that the shareholder with a high number of shares has tried to consider his individual interests instead of the interests for the benefit of the enterprise as he has become dominant in making decision on activities of the enterprise (Kakilli-Acaravcı, Kandır and Zelka, 2015). It is said that the fewer individuals with the majority of the shares the more concentrated ownership structure in the enterprise as inversely proportional. Therefore, it is stated that the higher the percentage of shares owned by a small number of shareholders or a single shareholder in the enterprise 
the greater the chance for the enterprise to have an ownership structure with concentration at the same ratio (Fettahoğlu and Okuyan, 2009). The largest shareholder's share ratio is calculated as the Largest Partner's Capital Amount/Total Equity (Bayrakdaroğlu, 2010). In the study conducted by La Porta et al. (1999), it has been found that the shareholders who own the majority of the current shares in the enterprise have increased their controlling power through a conglomeration and the shares providing a concession in voting as they have the majority of the shares. If a shareholder's percentage in the total shares is between $20 \%$ and $50 \%$, this shareholder has been called as a large shareholder due to the shares owned by him. In order that a shareholder can be defined as a controlling partner, the percentage of the shares owned by the shareholder must be in the above mentioned range (Pedersen and Thomsen, 1997).

The fact that a shareholder is defined as the controlling partner due to his majority in the total shares makes the relevant shareholder more advantageous than other shareholders in decision process and management of the enterprise. The controlling partner who is in the position of the largest shareholder may not be a partner of the enterprises for only investment purposes. The partnership can be established also for the purpose of participating in the managerial activities due to the high percentage of shares owned by the partner. Participating in an enterprise as a partner may be actualized by dominating the administration of the relevant enterprise or by having a representative in the board of directors to represent himself in the enterprise to be participated by the partner. Such participation is defined as a holding relationship with the simplest definition. The largest shareholder, namely, the largest partner of an enterprise can be a family owned enterprise as well as a foreign corporate investor (Sayman, 2012). As stated above, the components of ownership and control are collected in one-hand within the body of enterprise where the largest shareholder takes place in. Due to the relevant characteristic, such enterprises are known as the enterprises with a concentrated ownership structure (Kıyılar and Belen, 2005). Family owned enterprises, non-public offering enterprises and unlimited enterprises are some of the relevant types of enterprise (Gençtürk, 2003). In the enterprises with the largest shareholder, the controlling partner's tendency to follow the decisions taken by the management and the activities of the enterprise will increase in proportion to the increase in the number of shares owned by him. Such case will also decrease the conflicts of interest between the partners and the senior managers, namely, the cost of agency in the enterprise. The most important advantage of the largest shareholder, in other words, the controlling partner is appointment of the managers determined by him to the relevant enterprise. In the enterprises where the largest shareholder takes place in, any problem has not been encountered in making long-termed decisions. Therefore, it is possible to make long-termed investments in such enterprises (Berezneak, 2007).

\subsubsection{Free Float Rate (HAO)}

Before making a definition for the free float rate in the enterprises, the terms of the public offering and the publicly traded enterprise need to be explained. The term of the public offering can be defined as making the necessary regulations which provide the public with an opportunity to participate in the relevant enterprise because a shareholder within the capital structure of an enterprise which does not allow the public to become a shareholder. If an enterprise previously offered its shares to the public decides on the public offering again, such case is defined as the offering of a new share. However, if the shares of an enterprise with a closed capital structure are offered to the public for the first time, such case is defined as the initial public offering (Akbulak and Akbulak, 2004).

The ratio of an enterprise's publicly offered shares to the total shares owned by the enterprise is called as the free float rate. Though the distinction between control and ownership is significant in the enterprises where the ratio of publicly offered shares is high in the total, the ownership and the control are one within the other in the enterprises closed to the public. The enterprises with a high free float ratio provide the finance of investments to be made through borrowing. However, the rate of the debt to the equity is high in the enterprises where the free float ratio is not low (Turaboğlu, 2002). On the other hand, the rate of interest of the loan to be taken will also be high because the fact that the level of tangible assets is low, the concentration of the current assets on the certain items is high and the information regarding the enterprise cannot be accessed transparently by the firms which will meet the loan need in the non-publicly offered enterprises (Jensen and Meckling, 1976). Therefore, the non-public enterprises do not prefer to obtain finance by borrowing. Furthermore, the rate of loan to equity in the non-public enterprises is less than the rate in the publicly traded enterprises. The free float rate is a ratio determine what percentage of the total equity owned by the enterprise is offered to the public. Therefore, the rate to be used in the study is calculated as Total of the Publicly Traded Equity/Total Equity (Bayrakdaroğlu, 2010).

As the enterprises with a high free float rate have more resources in comparison to the enterprises in a closed structure, the relevant enterprises can make more investments in the tangible fixed assets. The tangible fixed assets owned by the enterprise determine the level of input used at the production stage in order that the manufacturing activities of the enterprise can be carried out. As the level of tangible fixed assets is high in the large scaled enterprises with a high free float rate, it can be said that the relevant enterprises have a higher capacity for production (Turaboğlu, 2002). 
The fact that the ownership structure of the enterprises with a high free float rate has a complex and broad-based nature provides many advantages. Economy of scope, which is defined as an opportunity to decrease the cost by producing many products through the use of the power of the enterprise in a certain area and to increase the product range through the experiences gained, can be given as an example for the advantages of the relevant ownership structure (Yayla, Kaya and Ekmen, 2005). Another example is that the enterprises with a high free float rate have more equity by means of their ownership structure and therefore have longer activity periods (Ağdelen and Erkut, 2008). There are some disadvantages of the public offering as well as the above advantages. One of these disadvantages is that the structure occurred due to the public offering makes the need of enterprises for professional managers compulsory (Büyükdereli, 2007). The partners who are afraid of losing the management of the enterprise want to keep the free float rate at a certain level. In case of the public offering, they enable the previous partners to have the right of priority during the sale of the shares (Sayman, 2012).

\subsubsection{Number of the Partners (ORTAK)}

The ownership structure of the enterprises is determined by the structure of the shareholders and the number of them in the enterprise. The size of the ownership structure, in other words, the number of the partners in the enterprise varies from enterprise to enterprise. The fact that this number is high indicates that the ownership of the enterprise has a broadbased structure which constitutes one of the main aims of the capital markets. As a result of ever increasing information exchange and communication opportunities between the parties, the ownership structures of the enterprises become diversified by the emerging markets (Sayman, 2012).

It is seen that it is highly probable the managers use the assets of the enterprise for their own interests in case that the managers in the enterprise have a small number of shares, the number of the shareholders is high and the shares belonging to the enterprise show an irregularity as a result of inclusion. It is stated that the reduction of the conflict of interest between the managers and the shareholders may be possible with an increase to be provided at the rate of the managers' shares (Jensen and Meckling, 1976).

The shareholders, who have the majority of shares in terms of the number, in other words, who have the authority to control the enterprise, may be able to obtain a benefit by directing the income of the enterprise to be obtained in accordance with their personal interests or to generate an income by using the assets belonging to the enterprise for the benefit of other entities they own (Yurtoglu, 2000).

In case that the shares of the enterprise belong to a large majority, the other groups, namely, the minority shareholders have very few rights and values. If voting on control of the enterprise becomes a current issue, importance of the minority group in terms of the right to vote is quite low. However, the voting right of this group is only important in the struggle to provide the individuals in different administrative positions within body of the enterprise with the votes. Moreover, another importance of the minority group comes to existence when there are many shareholders but there is not any ownership concentration, in other words, any group which controls the enterprise (Chung and Kim, 1999).

\subsubsection{Foreign Share (YABP)}

Foreign capital is classified in two categories as foreign direct investment and foreign indirect (portfolio) investment. Foreign direct investment is defined as the investments which provide a foreign enterprise with an opportunity to have the right to a full or partial ownership on an enterprise and its assets in another country. Foreign indirect investment refers to the financial transactions made with the result that a foreign enterprise abroad purchases the stocks and bonds in the ownership of an enterprise which is traded at the exchange of another country (Sağlamer, 2003). It is necessary to invest directly in the enterprises in other countries by the foreign individuals or institutions in order that the foreign ownership can be realized within the body of an enterprise. When we consider the realization of foreign capital investments from the viewpoint of the ownership, it is seen that the joint venture, company mergers and acquisitions are performed in the form of subsidiary company and considered as the investments made in order to ensure the ownership completely (Batmaz and Tekeli, 2009).

The joint venture, one of the types of realization of foreign direct investments, is defined as the way in which the foreign investors establish a new enterprise with shareholders of an enterprise carrying out its activities in a foreign country or participate in an existing enterprise as a partner. The joint venture is a type of foreign capital investment in which there is not any controlling shareholder for the ownership structure. One of the most important reasons for the foreign investors' decision on going into a partnership is that there are many legal restrictions in the country where the relevant enterprise to be invested by the investor takes place in (Yavan, 2006). As for the foreign investments in the full ownership, all transactions are carried out directly by the foreign enterprise which makes the investment. All investments made are completely under the control and ownership of the foreign enterprise (Altınışık, 2006). On the other hand, subsidiary enterprise is a type of enterprise actualized through the establishment of a new enterprise by the foreign investor in a foreign country or the purchase of $50 \%$ of the shares of the enterprise to be invested by a foreign investor. Due to the nature of the merger type, the foreign shareholders become the controlling shareholders of the subsidiary enterprise. Even 
if there are domestic shareholders within the ownership structure of such enterprises, all decisions of this new enterprise are taken by the foreign shareholders (Yavan, 2006).

\subsubsection{Corporate Investor Ratio}

Corporate investor ratio is a share indicator which states what percentage of the circulating shares of a publicly traded enterprise is purchased by the corporate investors. Increase of the relevant ownership in the enterprise means that the risk indicator of the enterprise is reduced and a less risky policy is pursued by comparison with other enterprises. Though this policy pursued may increase the performance of the enterprise, it may cause the enterprise, which tries to keep the risk level minimum, to encounter a problem in using the existing investment opportunities. Calculation of the corporate investor ownership is made as the Number of Shares of the Corporate Investors/the Number of Circulating Shares of the Enterprise (Kakilli-Acaravcı et al., 2015).

In the study conducted by Alfaraih, Alanezi and Almujamed (2012) and empirically examined the effects of the corporate ownership and the government ownership on the performance pf the enterprises in the Kuwait Stock Exchange, both Tobin's $Q$ which is a market based measure and the Return on Assets (ROA) which is an accounting based performance indicator were used to measure the performance in the enterprise. In the results of regression analysis of the study examined 134 enterprises listed on the Kuwait Stock Exchange in 2010, a positive relationship has been observed between the corporate investor ratio and the performance of the enterprises. Furthermore, it has been emphasized that the corporate investors have a dominant and effective role as a corporate governance mechanism. On the other hand, a negative relationship has been observed between the government ownership and the performance of the listed enterprises. In addition, it has been stated that the performance observed in the enterprises is worse when the government ownership exists. Results from the study indicate that different types of ownership have different effects on performance of the enterprise. Though the performance of the enterprises is increased by some of the ownership structures, it has been observed that some ownership structures worsen the performance.

\subsubsection{Firm Size}

In the studies on the ownership structure, measurements are performed using total assets, total equity and total sales as the firm size indicators. The firm size is included in the relevant models formed as the control variables in the studies which measure the relationship between the ownership structure and the performance of the enterprise. The main reason of the relevant case is that it is thought both the procedures regarding the ownership structure and the size of enterprise may be effective on the financial performance. Using the total assets as the firm size in the study, the logarithm of the total assets of the firm in the relevant years is calculated and included in the model in order to provide a compatibility with other variables.

Large firms are more effective than small firms as they can effectively benefit from the economy of scale. However, the enterprises may be faced with risks such as financial unprofitability and performance decrease as they develop in terms of the size. Therefore, the effect of the firm size on financial performance has become a controversial topic (Majumdar, 1997).

As the enterprise value decreases in the small scaled enterprises, the share of direct bankruptcy cost in the enterprise value will increase. Such case means the increase of the borrowing rates because the enterprise value increases (Fıratoğlu, 2005). As the enterprise size increases, the share of the managerial ownership in the enterprise will also show an increase. Therefore, the costs of agency and the moral risk terms are highly associated with each other. Furthermore, the growth in the enterprise size may also affect the need to work with more professional managers (Ünlü, Bayrakdaroğlu and Şamiloğlu, 2011).

\subsection{Research Models and Hypotheses}

The following conceptual models and hypotheses have been developed in accordance with the aim and scope of this study, and the effect of the ownership structure on financial performance of the enterprises has been investigated. The main hypotheses to be tested in this study are stated in the Table 4. In accordance with the literature, two main hypotheses were developed. In the following parts of the study, the effect of the variables related to the ownership structure on the return on the performance indicators called as the return on assets and the return on equity will be tested through the models developed and in accordance with the main hypotheses. Conceptual framework is shown in the Figure 1. 
Figure 1: Conceptual Framework

OWNERSHIP STRUCTURE
Share of the Largest Partner
Free Float Rate
Number of the Partners
Foreign Share
Corporate Investor Ratio
Firm Size

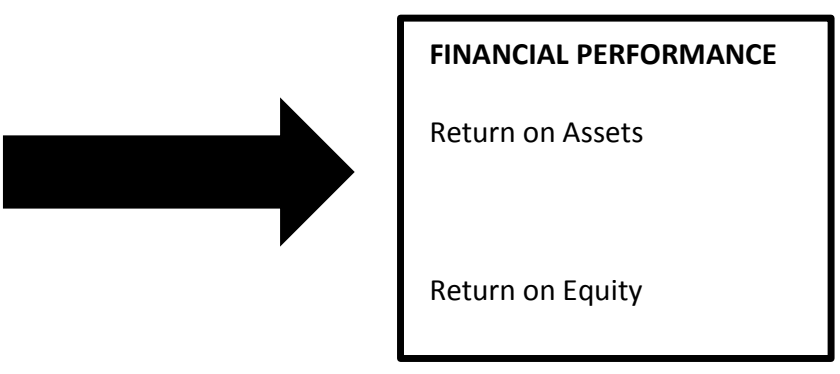

$H_{1}$ : The ownership structure affects the return on assets of the enterprises.

a) The share of the largest partner affects the return on assets of the enterprise.

b) The free float rate affects the return on assets of the enterprise.

c) The corporate investor ratio affects the return on assets of the enterprise.

d) The number of the partners affects the return on assets of the enterprise.

e) The foreign share affects the return on assets of the enterprise.

f) The size of assets affects the return on assets of the enterprise.

$H_{2}$ : The ownership structure affects the return on equity of the enterprises.

a) The share of the largest partner affects the return on equity of the enterprise.

b) The free float rate affects the return on equity of the enterprise.

c) The corporate investor ratio affects the return on equity of the enterprise.

d) The number of the partners affects the return on equity of the enterprise.

e) The foreign share affects the return on equity of the enterprise.

f) The size of assets affects the return on equity of the enterprise.

As $2 x(1+1)=4$, four models formed in the study are as follows: Two models which include five independent variables of the ownership structure (EBOP, HAO, KURY, ORTAK, YABP) and two dependent financial variables (ROA, ROE), and separately two additional models in which one of them includes the control variable (VALOG) and the other one does not include any control variable.

Table 4: Models in which the Ownership Structure is an Independent Variable

\begin{tabular}{|c|c|c|c|c|c|}
\hline & $\begin{array}{c}\text { Model } \\
1\end{array}$ & $\begin{array}{c}\text { Model } \\
2 \\
\end{array}$ & $\begin{array}{c}\text { Model } \\
\mathbf{3} \\
\end{array}$ & $\begin{array}{c}\text { Model } \\
4 \\
\end{array}$ \\
\hline & & A & B & A & B \\
\hline \multirow{2}{*}{ 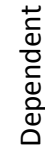 } & ROA & + & + & & \\
\hline & ROE & & & + & + \\
\hline \multirow{5}{*}{ 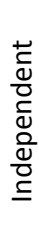 } & EBOP & + & + & + & + \\
\hline & HAO & + & + & + & + \\
\hline & KURY & + & + & + & + \\
\hline & ORTAK & + & + & + & + \\
\hline & YABP & + & + & + & + \\
\hline 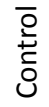 & VALOG & & + & & + \\
\hline
\end{tabular}

\subsection{Research Methods and Findings}

Different types of data sets can be used when econometric studies are conducted. The data sets on various types can be explained through the models which are appropriate for the structures. When the literature is considered, it is seen that three types of data sets are used as cross-sectional data, time series data and panel data in the studies. In the relevant 
study, the effect of the ownership structure and the capital structure on financial performance of the enterprise has been examined by the panel data analysis. The data have been analyzed by using the program called Eviews 8.0. Descriptive statistics calculated for the independent variables to be used in the regressions will be included in the study. The variables will be examined in terms of their mean, median, maximum, minimum, standard deviation, kurtosis, skewness and JarqueBera values. Any significant relationship should not be found between the independent variables used in the regression in order to prevent the problem of multicollinearity in the regression to be analyzed in the study. In order to determine the relevant situation, a correlation analysis will be made between the variables before predicting the models. The econometric methods used in empirical analyses vary by the types of data. The method which analyzes the data of the different units at the same point of time is called as the 'cross-sectional' data analysis, and the method which analyzes the change of the same units in time is called as the 'time series' analysis. The type of analysis made by using the cross-sectional data with time dimension is expressed as 'panel data' analysis. The problem of multicollinearity is less observable between the variables with the panel data, increases the descriptive capacity of the analysis or gives an opportunity to conduct the econometric analyses even when there are insufficient cross-sectional observation and short time series (Baltagi, 1995).

Due to the abovementioned advantages, there are some disadvantages of the panel data analysis which brings the crosssectional analysis and the time series analysis together. If the data are not stationary in the dimension of the time series of the panel data, in other words, if there is a unit root problem in the data, the results to be obtained from the regression analysis will be misleading. The unit root tests will be made in order to determine whether the data are stationary.

There are many unit root tests used in order to determine whether the data are stationary in the panel data analysis. These tests are used both for the balanced panel data and the unbalanced panel data. LLC (Levin, Lin and Chu, 2002; Levin and Lin, 1992; 1993), IPS (Im, Pesaran and Shin, 1997; 2003), Hadri LM (Hadri, 2000), Maddala and Wu (1999), Harris and Tzavalis (1999), Breitung (2000) and Harris-Sollis (2003) are some of the relevant tests. The distinctive characteristic of these tests is that they are used in the analysis of balanced panel data. If the data are sorted imbalancedly, Fisher-type unit root tests preferred based on the LLC test and the Augmented Dickey-Fuller (1979) test are selected. Within the scope of this study, the above unit root tests will be used based on the data characteristics and the results will be reported. The panel data analysis provides an opportunity to work with a wider data, allows the unobservable variables to be associated with the independent variables, gives a higher degree of freedom, and offers an opportunity to analyze the data with its heterogeneity. The linear panel data model is ordinarily as follows:

$$
y_{i t}=\beta_{0}+\beta_{1} x_{1 i t}+\beta_{2} x_{2 i t}+\beta_{3} x_{3 i t}+\cdots+\alpha_{i}+u_{i t}, i=1,2, \ldots, N ; t=1,2, \ldots, t
$$

In the model; $y_{i t}$ defines the dependent variable, $x_{i t}$ defines the independent variables, $\beta$ defines the coefficient parameters, $\alpha_{i}$ defines the unobservable individual effects which are stationary in the time dimension, $i$ defines the crosssectional unit, $t$ defines the time period and $u_{i t}$ defines the error term.

In the study, the linear panel data methods will be used as an estimator method for the panel data. These methods are the Fixed Effects Method and the Random Effects Method. Furthermore, the results of the Hausman test which determines if the method of Fixed or Random Effects should be used in the analysis will be discussed.

In the Fixed Effects method, the fixed effect estimator allows the unobservable individual effects in time $\left(\alpha_{i}\right)$ to be associated with the independent variables. The model, which is obtained through the time average of the unidirectional non-observable components model in the equality numbered (2) and the unidirectional non-observable components model in the equality numbered (3), has been stated.

$$
\begin{aligned}
& y_{i t}=\beta_{0}+\beta_{1} x_{i t}+\alpha_{i}+u_{i t}, i=1,2, \ldots, N ; t=1,2, \ldots, t \\
& \bar{y}_{i}=\beta_{1} \bar{x}_{i}+\alpha_{i}+\bar{u}_{i}, t=1,2, \ldots, t \\
& y_{i t}-\bar{y}_{i}=\beta_{1}\left(x_{i t}-\bar{x}_{i}\right)+\left(u_{i t}-\bar{u}_{i}\right), i=1,2, \ldots, N ; t=1,2, \ldots, t \\
& \ddot{y}_{i t}=\beta_{1} \ddot{x}_{i t}+\ddot{u}_{i t}, i=1,2, \ldots, N ; t=1,2, \ldots, t
\end{aligned}
$$

By subtracting these two equations from each other, the equation numbered (4) which is also called within transformation has been obtained. The equation numbered (5) is a representation with differential operator of the equation numbered (4). If the Pooled Least Squares estimation method is applied to the model, the fixed effects estimator is found (Wooldridge, 2010). 
In the random effects method, it is assumed that the unobservable individual fixed effects in the time dimension are not associated with all the descriptive variables in all time dimensions. In the relevant method, the Generalized Least Squares (GLS) estimation method is used as the error term includes autocorrelation. By the Generalized Least Squares method, the standard errors and the statistics of $t$ and $F$ become valid again. In the equation numbered (6), the model with transformation of the Generalized Least Squares is stated.

$y_{i t}-\theta \bar{y}_{i}=\beta_{1}\left(x_{i t}-\theta \bar{x}_{i}\right)^{T}+\left(v_{i t}-\theta \bar{v}_{i}\right)$

In the equation; $y_{i t}$ defines the dependent variable, $\theta$ defines the coefficient used in transformation of the GLS, $x_{i t}$ defines the independent (descriptive) variable, $v_{i t}$ defines the error margin transformed and $\left(v_{i t}=\alpha_{i}+u_{i t}\right)$ ve $\bar{y}_{i}, \bar{x}_{i}, \bar{v}_{i}$ define the time average of the variables. As it is seen in the equation numbered (6), the Random Effects estimator subtracts only the rate of $\theta$ of the time averages (Baltagi, 2005).

The main difference between the Fixed Effects and the Random Effects is resulted from the relationship of the fixed individual effects in the time dimension with the independent variables. Though the Fixed Effects model allows the fixed individual effects in the time dimension for the relationship with the independent variables, the Random Effects model does not allow for the fixed individual effects in the time dimension for the relationship with the independent variables. The Hausman Test, which identifies which method gives more consistent results and whether the difference between the estimators of the two methods is statistically significant in the model, determines the results. Accordingly, the test statistic is stated below:

$H=\left(\hat{\beta}_{F E}-\hat{\beta}_{R E}\right)^{T}\left[\operatorname{Avar}\left(\hat{\beta}_{F E}\right)-\operatorname{Avar}\left(\hat{\beta}_{R E}\right)\right]^{-1}\left(\hat{\beta}_{F E}-\hat{\beta}_{R E}\right)$

$\hat{\beta}_{F E}$ indicates the fixed effects estimator, $\hat{\beta}_{R E}$ indicates the random effects estimator and Avar identifies the asymptotic variance of them. The null hypothesis $\left(H_{0}\right)$ of the Hausman Test which shows the $\chi^{2}$ distribution with the degree of freedom determined by $k$ is as "The method of Random Effects is consistent" (Greene, 2003). In the test result, the rejection of $H_{0}$ indicates that the method of Fixed Effects should be preferred.

Time series are the sequence of the observations made at periodical time intervals. One of the most important issues in the times series is stability. Almost all the statistical inferences are made through the assumption of the stability in the series. If there is not any stability, the series must be stabilized in any way before proceeding to the conclusion (Akdi, 2010). As in all the analyses of time series, the variables should be stable in order to prevent the false relationships between the variables in the panel data analysis which performs both time series and the cross-sectional analyses together. It is suggested that the stability should be examined in two ways. The common unit root process was examined with Levin, Lin \& Chu (2002) test and each unit was examined with Im, Pesaran \& Shin (2003) test and ADF-Fisher Chi-Square test. Results of the panel unit root test are shown in the Table 5. The unit roots were first examined in the level; when the unit root is detected in the relevant level, it is stabilized by taking the first or second differences respectively.

Table 5: Descriptive Statistics and Stability (Unit Root) Test Results of the Industrial Index Series

\begin{tabular}{|l|l|l|l|l|l|l|l|l|l|l|l|}
\hline Series & $\mathbf{X}$ & $\mathbf{S S}$ & $\mathbf{M d}$ & $\mathbf{M n}$ & $\mathbf{M x}$ & $\mathbf{S}$ & $\mathbf{K}$ & JB & LLC & IPS \\
\hline ROA & 0,05 & 0,09 & 0,05 & $-0,51$ & 0,70 & 0,27 & 7,54 & $879,3^{* *}$ & $-28,721^{* *}$ & $-6,100^{* *}$ & $384,019^{* *}$ \\
\hline LROE & $-1,18$ & 0,10 & $-1,18$ & $-2,41$ & 0,00 & $-0,91$ & 43,3 & $6837^{* *}$ & $-22,495^{* *}$ & $-4,873^{* *}$ & $358,877^{* *}$ \\
\hline EBOP & 0,50 & 0,21 & 0,50 & 0,00 & 0,99 & 0,10 & 2,44 & $14,79 * *$ & - & $1189,73^{* *}$ & $-7580,91^{* *}$ \\
\hline L(D2HAO) & $-0,50$ & 0,06 & $-0,50$ & $-0,85$ & 0,00 & $-0,83$ & 20,82 & $11693^{* *}$ & $-45,390^{* *}$ & $-4,503^{* *}$ & $275,045^{* *}$ \\
\hline LKURY & 0,44 & 0,22 & 0,44 & 0,00 & 0,99 & 0,16 & 2,54 & $13,41^{* *}$ & $-27,248^{* *}$ & $-4,956^{* *}$ & $355,621^{* *}$ \\
\hline ORTAK & 1,35 & 0,81 & 1,00 & 0,00 & 4,00 & 0,60 & 3,56 & $75,71^{* *}$ & $-26,047^{* *}$ & $-6,498^{* *}$ & $109,204^{* *}$ \\
\hline LYABP & $-4,60$ & 2,74 & $-3,81$ & $-13,81$ & 0,02 & $-0,96$ & 3,63 & $171,8^{* *}$ & $-42,158^{* *}$ & $-10,642^{* *}$ & $491,237^{* *}$ \\
\hline VALOG & 19,69 & 1,39 & 19,54 & 16,29 & 23,8 & 0,38 & 2,93 & $25,22^{* *}$ & $-18,231^{* *}$ & $-4,057^{* *}$ & $345,839^{* *}$ \\
\hline
\end{tabular}

${ }^{*} \mathrm{p}<0,05 * * \mathrm{p}<0,01^{1}$ : Asymptotic $\mathrm{X}^{2}$

The statistical method, which is used to test the heteroscedasticity of the error term frequently seen in the panel data econometry, is the Lagrange Multiplier (LM) test (Greene, 2003). For this purpose, the test of Breusch-Pagan LM and Pesaran Scaled LM were utilized. 
H0: Heteroscedasticity does not exist

$\mathrm{H} 1$ : Heteroscedasticity exists.

When the problem of heteroscedasticity is encountered, correction of the standard errors in the fixed effects models was made by White's Diagonal Coefficient Covariance method, and the Cross-Section Weighted GLS was applied. However, correction of the standard errors in the random effects models was made by White's cross sectional coefficient covariance method, and Swamy-Arora weighted GLS was applied (Kyriazis and Anastassis, 2007).

In the panel data regression estimation, the Hausman test was used in order to determine which method of estimation (with fixed or random effects) should be used. The Hausman test is a method used to decide on the model to be preferred when it is necessary to make a choice between the fixed effects models and the random effects models (Greene, 2003). Based on the $\mathrm{X}^{2}$ statistic obtained from the Hausman test, the model to be used has been determined.

HO: The random effects model is suitable.

$\mathrm{H} 1$ : The fixed effects model is suitable.

Variance inflation factor (VIF) and correlation between the variables were examined in order to consider the problem of multicollinearity before the panel data regression. If the simple (bivariate) correlation between the independent variables is 0.71 and above, there is a high relationship between the variables. On the other hand, the fact that the correlation is above 0.90 is the indicator of multicollinearity. In case that the correlation coefficient is above 0.70 , it is necessary to examine the variance inflation factors (VIF) separately for each model. As a rule, the multicollinearity will be discussed in case that the VIF is equal to 10 or higher. Therefore, one of the binary variables should be subtracted from the model (Çokluk, Şekercioğlu, Büyüköztürk, 2010).

Table 6: Results of the Correlation Analysis between the Industrial Index Variables

\begin{tabular}{|cl|l|l|l|l|l|l|l|l|}
\hline Variables & 1 & 2 & 3 & 4 & 5 & 6 & 7 & 8 \\
\hline $1 . \quad$ ROA & 1,00 & $-\mathbf{0 , 7 1}$ & 0,02 & 0,05 & $-0,04$ & 0,04 & 0,00 & 0,02 \\
\hline $2 . \quad$ SROE & & 1,00 & 0,00 & $-0,01$ & 0,01 & 0,00 & $-0,08$ & $-0,06$ \\
\hline $3 . \quad$ EBOP & & & 1,00 & 0,06 & 0,33 & $-0,34$ & 0,02 & $-0,04$ \\
\hline $4 . \quad$ LDHAO & & & & 1,00 & 0,08 & $-0,01$ & 0,02 & 0,01 \\
\hline $5 . \quad$ SKURY & & & & & 1,00 & $-0,18$ & 0,35 & 0,04 \\
\hline $6 . \quad$ ORTAK & & & & & & 1,00 & 0,05 & 0,17 \\
\hline $7 . \quad$ LYABP & & & & & & & 1,00 & 0,40 \\
\hline 8. VALOG & & & & & & & & 1,00 \\
\hline
\end{tabular}

$\mathrm{T}$ is used to indicate the terms. While $\mathrm{N}$ indicates the total number of the enterprises, $\mathrm{T}$ defines the total number of the terms.

Table 7: Model 1A Panel Regression Analysis Results

\begin{tabular}{|c|c|c|c|c|c|}
\hline \multicolumn{6}{|l|}{ Dependent Variable: ROA } \\
\hline \multicolumn{6}{|l|}{ Method: Panel LS\&AR } \\
\hline Independent Variables* & Coefficient & SH & $\mathbf{T}$ & p & VIF \\
\hline EBOP & 0,046 & 0,025 & 1,880 & 0,060 & 1,12 \\
\hline LDHAO & $-0,093$ & 0,042 & $-2,218$ & 0,027 & 1,01 \\
\hline SKURY & $-0,101$ & 0,022 & $-4,538$ & 0,000 & 1,26 \\
\hline ORTAK & 0,001 & 0,006 & 0,142 & 0,887 & 1,06 \\
\hline LYABP & 0,002 & 0,002 & 1,502 & 0,134 & 1,17 \\
\hline $\mathrm{C}$ & 0,036 & 0,029 & 1,263 & 0,207 & \\
\hline Number of the panel variables observed & 890 & & Model F & 5,134 & \\
\hline Number of the cross sections included & 112 & & Prob(F) & 0,000 & \\
\hline Hausman $\left(X^{2}\right)$ & 5,072 & & $\begin{array}{l}\text { Durbin } \\
\text { Watson }\end{array}$ & 1,651 & \\
\hline Prob Hausman $\left(\mathrm{X}^{2}\right)$ & 0,407 & & $\Delta R^{2}$ & 0,023 & \\
\hline Model & Random Effects & & & & \\
\hline Heteroscedasticity & & $\begin{array}{l}\text { LM1 } \\
x^{2}=8411,06 \\
p=0,000\end{array}$ & $\begin{array}{l}\mathrm{LM} 2 \\
x^{2}=18,682 \\
p=0,000\end{array}$ & & \\
\hline Correction & \multicolumn{4}{|c|}{$\begin{array}{l}\text { White cross-section } \\
\text { Swamy-Arora }\end{array}$} & \\
\hline
\end{tabular}


As the $\mathrm{HO}$ hypothesis which indicates the random effects model is more effective than the fixed effects model in the model1a formed for ROA dependent variable was accepted as a result of the Hausman test $\left(X^{2}=5,07 ; p>0,05\right)$, the random effects method was used in the panel data estimation for the model1a. It has been found that the model is significant $(F=5,13 ; p<0,01)$ in the random effects panel regression equation made for the model1a. Furthermore, it has been determined that the variables of HAO $(t=-2,22 ; p<0,05)$ and KURY $(t=-4,54 ; p<0,01)$ have a significant effect on the ROA. It has been seen that all the variables included in the model indicate averagely $2 \%$ of the variance in the ROA variable. As a result, it has been considered that the variance is real as the Durbin Watson score $(D W=1,65)$ is higher than the $R^{2}$. The results are shown in Table 7.

$$
\text { ROA }=0,04+0,05 * E B O P-0,09 * H A O-0,10 * K U R Y+0,00 * O R T A K+0,00 * Y A B P+\varepsilon_{i t}
$$

Table 8: Model 1B Panel Regression Analysis Results

\begin{tabular}{|c|c|c|c|c|}
\hline \multicolumn{5}{|l|}{ Dependent Variable: ROA } \\
\hline \multicolumn{5}{|l|}{ Method: Panel LS\&AR } \\
\hline Independent Variables & Coefficient & SH & $\mathbf{t}$ & $\mathbf{p}$ \\
\hline VALOG & 0,009 & 0,005 & 1,745 & 0,081 \\
\hline EBOP & 0,041 & 0,034 & 1,187 & 0,236 \\
\hline LDHAO & $-0,089$ & 0,017 & $-5,108$ & 0,000 \\
\hline SKURY & $-0,097$ & 0,022 & $-4,344$ & 0,000 \\
\hline ORTAK & $-0,001$ & 0,005 & $-0,202$ & 0,840 \\
\hline LYABP & 0,001 & 0,002 & 0,702 & 0,483 \\
\hline $\mathrm{C}$ & $-0,146$ & 0,127 & $-1,154$ & 0,249 \\
\hline Number of the panel variables observed & 890 & & Model F & 5,222 \\
\hline Number of the cross sections included & 112 & & Prob(F) & 0,000 \\
\hline Hausman $\left(X^{2}\right)$ & 4,544 & & Durbin Watson & 1,651 \\
\hline Prob Hausman $\left(X^{2}\right)$ & 0,603 & & $\Delta R^{2}$ & 0,027 \\
\hline Model & Random Effects & & & \\
\hline Heteroscedasticity & & $\begin{array}{l}\text { LM1 } \\
x^{2}=8499,7 \\
p=0,000\end{array}$ & $\begin{array}{l}\text { LM2 } \\
x^{2}=19,47 \\
p=0,000\end{array}$ & \\
\hline Correction & \multicolumn{4}{|c|}{$\begin{array}{l}\text { White cross-section } \\
\text { Swamy-Arora }\end{array}$} \\
\hline
\end{tabular}

As the $\mathrm{HO}$ hypothesis which indicates the random effects model is more effective than the fixed effects model in the model $1 b$ formed for ROA dependent variable and included VALOG as a control variable was accepted as a result of the Hausman test $\left(X^{2}=4,54 ; p>0,05\right)$, the random effects method was used in the panel data estimation for the model $1 \mathrm{~b}$. It has been found that the model is significant $(F=5,22 ; p<0,01)$ in the random effects panel regression equation made for the model $1 b$. Furthermore, it has been determined that the variables of HAO $(t=-5,11 ; p<0,01)$ and $K U R Y(t=-4,34 ; p<0,01)$ have a significant effect on the ROA. It has been seen that all the variables included in the model indicate averagely $3 \%$ of the variance in the ROA variable. As a result, it has been considered that the variance is real as the Durbin Watson score $(D W=1,65)$ is higher than the $R^{2}$. Based on the Model1b results, it has been seen that there is not any increase in the total variance obtained after involving the variable of VALOG in the model (Model2A $R^{2}=0,02$; Model2b $R^{2}=0,03$ ). The results are shown in Table 8.

$$
\text { ROA }=-0,15+0,01 * \text { VALOG }+0,04 * \text { EBOP- 0,09*HAO - 0,10*KURY + 0,00*ORTAK + 0,00*YABP }+\varepsilon_{i t}
$$

H1a Rejection : EBOP variable has not any significant effect on the ROA.

H1b Acceptance : HAO variable has a negatively significant effect on the ROA.

H1c Acceptance : KURY variable has a negatively significant effect on the ROA.

H1d Rejection : ORTAK variable has not any significant effect on the ROA.

H1e Rejection :YABP variable has not any significant effect on the ROA.

H1f Rejection : VALOG variable has not any significant effect on the ROA. 
Table 9: Model 2A Panel Regression Analysis Results

\begin{tabular}{|c|c|c|c|c|c|}
\hline \multicolumn{6}{|l|}{ Dependent Variable: SROE } \\
\hline \multicolumn{6}{|l|}{ Method: Panel LS\&AR } \\
\hline Independent Variables* & Coefficient & SH & $\mathbf{t}$ & p & VIF \\
\hline EBOP & 0,031 & 0,040 & 0,785 & 0,433 & 3,49 \\
\hline LDHAO & $-0,070$ & 0,045 & $-1,547$ & 0,122 & 4,25 \\
\hline SKURY & $-0,119$ & 0,036 & $-3,336$ & 0,001 & 6,03 \\
\hline ORTAK & 0,002 & 0,003 & 0,531 & 0,595 & 1,95 \\
\hline LYABP & 0,003 & 0,001 & 2,674 & 0,008 & 2,45 \\
\hline $\mathrm{C}$ & $-1,172$ & 0,025 & $-47,021$ & 0,000 & \\
\hline $\begin{array}{l}\text { Number of the panel variables } \\
\text { observed }\end{array}$ & 890 & & Model F & 5,690 & \\
\hline Number of the cross sections included & 112 & & $\operatorname{Prob}(\mathrm{F})$ & 0,000 & \\
\hline Hausman $\left(X^{2}\right)$ & 7,943 & & Durbin Watson & 1,667 & \\
\hline Prob Hausman $\left(X^{2}\right)$ & 0,159 & & $\Delta \mathrm{R}^{2}$ & 0,026 & \\
\hline Model & Random Effects & & & & \\
\hline Heteroscedasticity & & $\begin{array}{l}\text { LM1 } \\
x^{2}=8177,6 \\
p=0,000\end{array}$ & $\begin{array}{l}\mathrm{LM} 2 \\
x^{2}=16,59 \\
p=0,000\end{array}$ & & \\
\hline Correction & $\begin{array}{l}\text { White cross-sect } \\
\text { Swamy-Arora }\end{array}$ & & & & \\
\hline
\end{tabular}

As the $\mathrm{HO}$ hypothesis which indicates the random effects model is more effective than the fixed effects model in the model2a formed for ROA dependent variable was accepted as a result of the Hausman test $\left(X^{2}=7,94 ; p>0,05\right)$, the random effects method was used in the panel data estimation for the model2a. It has been found that the model is significant $(F=5,69 ; p<0,01)$ in the random effects panel regression equation made for the model2a. Furthermore, it has been determined that the variables of KURY $(t=-0,12 ; p<0,01)$ and $Y A B P(t=2,67 ; p<0,01)$ have a significant effect on the ROA. It has been seen that all the variables included in the model indicate averagely $3 \%$ of the variance in the ROA variable. As a result, it has been considered that the variance is real as the Durbin Watson score $(D W=1,67)$ is higher than the $R^{2}$. The results are shown in Table 9.

$$
\text { ROE }=-1,17+0,03 * \text { EBOP- 0,07*HAO- 0,12*KURY + 0,00*ORTAK + 0,00*YABP }+\varepsilon_{i t}
$$

Table 10: Model 2B Panel Regression Analysis Results

\begin{tabular}{|c|c|c|c|c|}
\hline \multicolumn{5}{|l|}{ Dependent Variable: SROE } \\
\hline \multicolumn{5}{|l|}{ Method: Panel LS\&AR } \\
\hline Independent Variables & Coefficient & SH & $\mathbf{t}$ & $\mathbf{p}$ \\
\hline VALOG & 0,012 & 0,005 & 2,526 & 0,012 \\
\hline EBOP & 0,023 & 0,040 & 0,589 & 0,556 \\
\hline LDHAO & $-0,064$ & 0,040 & $-1,623$ & 0,105 \\
\hline SKURY & $-0,111$ & 0,033 & $-3,360$ & 0,001 \\
\hline ORTAK & $-0,001$ & 0,004 & $-0,296$ & 0,768 \\
\hline LYABP & 0,001 & 0,002 & 0,676 & 0,499 \\
\hline $\mathrm{C}$ & $-1,409$ & 0,105 & $-13,385$ & 0,000 \\
\hline $\begin{array}{l}\text { Number of the panel variables } \\
\text { observed }\end{array}$ & 890 & & Model F & 6,657 \\
\hline Number of the cross sections included & 112 & & Prob(F) & 0,000 \\
\hline Hausman $\left(X^{2}\right)$ & 6,721 & & Durbin Watson & 1,675 \\
\hline Prob Hausman $\left(\mathrm{X}^{2}\right)$ & 0,347 & & $\Delta \mathrm{R}^{2}$ & 0,037 \\
\hline Model & Random Effects & & & \\
\hline Heteroscedasticity & & $\begin{array}{l}\text { LM1 } \\
x^{2}=8230,6 \\
p=0,000\end{array}$ & $\begin{array}{l}\text { LM2 } \\
x^{2}=17,06 \\
p=0,000\end{array}$ & \\
\hline Correction & \multicolumn{4}{|l|}{$\begin{array}{l}\text { White cross-section } \\
\text { Swamy-Arora }\end{array}$} \\
\hline
\end{tabular}


As the $\mathrm{HO}$ hypothesis which indicates the random effects model is more effective than the fixed effects model in the model $2 \mathrm{~b}$ formed for ROA dependent variable and included VALOG as a control variable was accepted as a result of the Hausman test $\left(X^{2}=6,72 ; p>0,05\right)$, the random effects method was used in the panel data estimation for the model $2 b$. It has been found that the model is significant $(F=6,66 ; p<0,05)$ in the random effects panel regression equation made for the model $2 b$. Furthermore, it has been determined that the variables of VALOG $(t=2,53, p<0,05)$ and KURY $(t=-3,36 ; p<0,01)$ have a significant effect on the ROA. It has been seen that all the variables included in the model indicate averagely $4 \%$ of the variance in the ROA variable. As a result, it has been considered that the variance is real as the Durbin Watson score $(D W=1,68)$ is higher than the $R^{2}$. Based on the Model3b results, it has been seen that there is not any increase in the total variance obtained after involving the variable of VALOG in the model (Model $3 a R^{2}=0,03$; Model $3 b R^{2}=0,04$ ). The results are shown in Table 10.

$$
\text { ROE }=-1,41+0,01 * \text { VALOG }+0,02 * \text { EBOP- 0,06*HAO- 0,11*KURY + 0,00*ORTAK + 0,00*YABP }+\varepsilon_{i t}
$$

H2a Rejection : : EBOP variable has not any significant effect on the ROE.

$\mathrm{H} 2 \mathrm{~b}$ Rejection : HAO variable has not any significant effect on the ROE.

H2c Acceptance : KURY variable has a negatively significant effect on the ROE.

$\mathrm{H} 2 \mathrm{~d}$ Rejection : ORTAK variable has not any significant effect on the ROE.

H2e Acceptance : YABP variable has a positively significant effect on the ROE.

$\mathrm{H} 2 \mathrm{f}$ Acceptance : VALOG variable has a positively significant effect on the ROE.

\section{CONCLUSION}

In this study, the effects of the ownership structure in the enterprises traded on Borsa Istanbul (BIST) and included in the industrial index on their financial performance are examined in the light of accounting based performance indicators. It has been benefited from the data of 112 enterprises which are traded on the relevant index and carry out their activities uninterruptedly during the period between the years of 2006 and 2014. The relationship between the share of the largest partner, the corporate investor ratio, the free float rate, the number of partners and the foreign share used as the variables of ownership structure and the "Return on Assets" and the "Return on Equity" used as the indicators of financial performance has been analyzed.

In accordance with the results of the panel data regression analysis made for the ROA, it has been found that the free float rate and the corporate investor ratio have a negatively and statistically significant effect on the return on assets in the enterprises. Therefore, it can be interpreted that the increase in the free float rate and the corporate investor ratio has increased the share risk and the share price of the enterprises. Furthermore, the increase seen in the free float rate indicates that these firms are defined as the widely held firms. As the number of professional managers is high in management of such firms, it can be stated that these managers relatively manage the assets more effectively.

Based on the results of the panel data regression analysis made for the ROE which is the second model of the study, it has been found that the corporate investor ratio has a negatively and statistically significant effect on the return on assets and the return on equity. Furthermore, it has been determined that the foreign share and the size of total assets, it other words, the size of enterprise used as a control variable in the study have a positively and statistically significant effect on the return on equity. Therefore, the increase in the foreign share, namely, the change of the foreign partnership into the controlling shareholder may have a positive effect on financial performance of the enterprises and provide the shareholders with an opportunity to make more profitable investments. Furthermore, the foreign shareholders' power to control and audit the enterprises which show an increase in the level of foreign ownership will lead to a positive effect on financial performance of the enterprises.

It has been seen that the increase of the activity diversity on the cash flow has an effect to minimize the possible fluctuations, in other words, the risk of bankruptcy. As the large scaled enterprises benefit from the economy of scale effectively, they can be more effective than the small scaled enterprises. In the results of analyses made in the four models created for determination of the financial performance, any statistically significant relationship has not been found for the variables of the share of the largest partner and the number of partners.

Based on the research results, it has been seen that financial performance of the enterprises is not independent of the ownership structure. It can be said that the variables of ownership structure are effective on the accounting based financial performance indicators and that it is important to consider these variables in the characteristics and differences regarding the ownership structure of the enterprises while commenting the financial performance.

The results obtained from the research are important especially for the investors. Thus, the investors who aim to earn profit and increase their welfare will want to know the factors which affect the financial performance, in other words, the profitability of the enterprises with shares. It is expected that the results of this study will be beneficial for giving an idea for the enterprises which are traded on the BIST Industrial Index and different from each other in terms of the ownership 
structure. Though some results are compatible with the studies made on the relevant research in the literature up to the present, any compatibility has not been observed in some of them. The differences in the sector, year and variables used are effective factors for the incompatibility in the relevant studies made in the literature. Therefore, the results should be interpreted only for the enterprises, which carry out their activities in the relevant index, due to some restrictions. The enterprises in the index mentioned in the study consist of the enterprises which carry out their activities uninterruptedly in the relevant range of years. All enterprises listed on the relevant index have not been included in the scope of the analysis due to the restrictions.

In the following studies which will examine the relationship between the financial performance and the structures of capital and ownership, examinations can be made through a comparison of countries and sectors in the relevant indices in addition to the different indices and a wider data set.

\section{REFERENCES}

Ağdelen, Z. ve Erkut, H. (2008). Firma Kurumsal ve Yönetsel Özelliklerinin İnsan Kaynakları Yönetimi Üzerindeki Etkisinin Analizi, GAU Journal of Social and Applied Sciences, C.3, N.6, ss. 37-55.

Akbulak, S. ve Akbulak, Y. (2004). Türkiye'de Sermaye Piyasası Araçları ve Halka Açık Anonim Şirketler, 1. Baskı, Beta Yayınları, İstanbul.

Akdi, Y. (2010). Zaman Serileri Analizi (Birim Kökler ve Kointegrasyon), Genişletilmiş 2. Baskı, Gazi Kitabevi, Ankara.

Akdogan, Y.E. and Boyacioglu, M.A. (2014). The Effect of Corporate Governance on Firm Performance: A Case of Turkey, International Journal of Critical Accounting, V.6, N.2, pp. 187-210.

Akgüç, Ö. (1998). Finansal Yönetim, 7. Baskı, Avcıol Basım Yayın, İstanbul.

Albayrak, A.S. ve Akbulut, R. (2008). Kârlılığı Etkileyen Faktörler: iMKB Sanayi ve Hizmet Sektörlerinde İşlem Gören İşletmeler Üzerine Bir Inceleme, Zonguldak Karaelmas Üniversitesi Sosyal Bilimler Dergisi, C.4, S.7, ss. 55-83.

Alfaraih, M., Alanezi, F. and Almujamed, H. (2012). The Influence of Institutional and Government Ownership on Firm Performance: Evidence from Kuwait, International Business Research, V.5, N.10, pp. 192-200.

ALShubiri, F.N. (2011). The Effect of Working Capital Practices on Risk Management: Evidence from Jordan, Global Journal of Business Research, V.5, N.1, pp. 39-54.

Altınışık, A.E. (2006). Uluslararası Doğrudan Yabancı Sermaye Yatııımlarının Vergi Özendirmeleri Önlemleri Karşısındaki Durumu ve Vergisel Teşviklerinde Başarısında Çin. Yayınlanmamış Yüksek Lisans Tezi, İstanbul: Marmara Üniversitesi Sosyal Bilimler Enstitüsü.

Baltagi, B.H. (1995). Econometric Analysis of Panel Data, $1^{\text {st }}$ Edition, John Wiley \& Sons, Inc, New York.

Baltagi, B.H. (2005). Econometric Analysis of Panel Data, $3^{\text {rd }}$ Edition, John Wiley \& Sons, Ltd, Chichester.

Batmaz, N. ve Tekeli, S. (2009). Doğrudan Yabancı Sermaye Yatırımlarının Ekonomik Büyüme Üzerindeki Etkileri: Polonya, Çek Cumhuriyeti, Macaristan ve Türkiye Örneği (1996-2006), 1. Baskı, Ekin Basım Yayın Dağıtım, Bursa.

Bayrakdaroğlu, A. (2010). Mülkiyet Yapısı ve Finansal Performans: iMKB Örneği, Ekonomi Bilimleri Dergisi, V.2, N.2, pp. 11-20.

Berezneak, E. (2007). Bankalarda Kurumsal Yönetim Çerçevesinde Sahiplik Yapısı ve Performans ilişkisi: Türkiye Uygulaması. Yayınlanmamış Yüksek Lisans Tezi, İstanbul: Yıldız Teknik Üniversitesi Sosyal Bilimler Enstitüsü.

Berle, A.A. and Means, G.C. (1933). The Modern Corporation and Private Property, $1^{\text {st }}$ Edition, Macmillan Publishers, New York.

Brailsford, T.J., Oliver, B.R. and Pua, S.L.H. (2002). On The Relation Between Ownership Structure And Capital Structure, Accounting \& Finance, V.42, N.1, pp. 1-26.

Breitung, J. (2000). The Local Power of Some Unit Root Tests for Panel Data, in (Eds) Baltagi B. H., Fomby T. B., Hill R. C., Nonstationary Panels, Panel Cointegration and Dynamic Panels (Advances in Econometrics, Volume 15), pp. 161-177, Emerald Group Publishing Limited, UK.

Büyükdereli, M. (2007). IMKB'de Faaliyet Gösteren Reel Sektör Firmalarının Mülkiyet Yapısının, Bu Firmaların Finansal Performansları Üzerine Etkisi. Yayınlanmamış Yüksek Lisans Tezi, İstanbul: Marmara Üniversitesi Sosyal Bilimler Enstitüsü.

Büyükmert, N. (2015). İşletmelerde Sahiplik Yapısının Kârlılık ve Sermaye Yapısı Üzerine Etkileri: Borsa İstanbul’da Ampirik Bir Uygulama. Yayınlanmamış Yüksek Lisans Tezi, Balıkesir: Balıkesir Üniversitesi Sosyal Bilimler Enstitüsü.

Cenger, H. (2006). Genel İşletme Performansı ve Finansal Performans İlişkisi: Çimento Sektöründe Bir Uygulama. Yayınlanmamış Yüksek Lisans Tezi, Gaziantep: Gaziantep Üniversitesi Sosyal Bilimler Enstitüsü.

Chung, K.H. and Kim, J.K. (1999). Corporate Ownership and The Value of a Vote in An Emerging Market, Journal of Corporate Finance, V.5, N.1, pp. 35-54. 
Çokluk, Ö., Şekercioğlu G. ve Büyüköztürk, Ş. (2010). Sosyal Bilimler İ̧̧in Çok Değişkenli Istatistik: SPSS ve LISREL Uygulamaları, 1. Baskı, Pegem Akademi Yayıncilık, Ankara

Deesomsak, R., Paudyal, K. And Pescetto, G. (2004). The Determinants of Capital Structure: Evidence from The Asia Pacific Region, Journal of Multinational Financial Management, V.14, N.4-5, pp. 387-405.

Demsetz, H. and Villalonga, B. (2001). Ownership Structure and Corporate Performance. Journal of Corporate Finance, V.7, N.3, pp. 209233.

Demsetz, H. and Lehn, K. (1985). The Structure of Corporate Ownership: Causes and Consequences, Journal of Political Economy, V.93, N.6, pp. 1155-1177.

Dickey, D.A. and Fuller, W.A. (1979). Distribution of the Estimators for Autoregressive Time Series with a Unit Root, Journal of the American Statistical Association, V.74, N.366, pp. 427-431.

Doğan, M. ve Topal, Y. (2015). Sahiplik Yapısının Firma Performansı Üzerine Etkisi: Türkiye Örneği, Süleyman Demirel Üniversitesi Iktisadi ve Idari Bilimler Fakültesi Dergisi, V.20, N.4, ss. 165-177.

Ercan, M.K. ve Ban, Ü. (2005). Değere Dayalı Işletme Finansı Finansal Yönetim, 2. Baskı, Gazi Kitabevi, Ankara.

Escalona, R. (2002). Value-Based Management: An Analysis of the EVA Model. MBA Dissertation, Cambridge: University of Cambridge Judge Institute of Management Studies.

Fettahoğlu, A. ve Okuyan, H.A. (2009). İşletmelerde Sahiplik Yapısında Kaynak Bileşimi Üzerindeki Etkisi: iMKB'de Bir Uygulama, Anadolu Uluslararası Iktisat Kongresi Tebliği, Eskişehir, 17-19 Haziran, ss. 1-17.

Fıratoğlu, B. (2005). Şirketlerin Sermaye Yapısını Etkileyen Faktörler ve Kriz Dönemlerinde Şirket Davranışlarında Meydana Gelen Değişiklikler, Araştırma Raporu, Sermaye Piyasası Kurulu, Ankara.

Friend, I. and Lang, L.H.P. (1988). An Empirical Test of The Impact of Managerial Self-Interest on Corporate Capital Structure, The Journal of Finance, V.43, N.2, pp. 271-281.

Gençtürk, M. (2003). Finansal Kriz Dönemlerinde İşletmelerin Hisse Yoğunluklarının Performanslarına Etkisi, Süleyman Demirel Üniversitesi iktisadi ve Idari Bilimler Fakültesi Dergisi, C.8, S.2, ss. 231-251.

Grant, J.L. (2003). Foundations of Economic Value Added, The Frank J. Fabozzi Series, $2^{\text {nd }}$ Edition, John Wiley \& Sons, Inc, Hoboken, New Jersey.

Greene, W.H. (2003). Econometric Analysis, $5^{\text {th }}$ Edition, Pearson Education, Inc., Upper Saddle River, New Jersey.

Hadri, K. (2000). Testing for Stationarity in Heterogeneous Panel Data, The Econometrics Journal, V.3, N.2, pp. 148-161.

Hall, M. and Weiss, L. (1967). Firm Size and Profitability, The Review of Economics and Statistics, V.49, N.3, pp. 319-331.

Harris, R. and Sollis, R. (2003). Applied Time Series Modelling and Forecasting, $1^{\text {st }}$ Edition, John Wiley \& Sons, Ltd, Chichester.

Harris, R.D.F. and Tzavalis, E. (1999). Inference for Unit Roots in Dynamic Panels Where the Time Dimension Is Fixed, Journal of Econometrics, V.91, N.2, pp. 201-226.

Himmelberg, C.P., Hubbard, R.G. and Palia, D. (1999). Understanding the Determinants of Managerial Ownership and The Link Between Ownership and Performance. Journal of Financial Economics, V.53, N.3, pp. 353-384.

Horngren, C.T., Foster, G. and Datar, S.M. (1999). Cost Accounting: A Managerial Emphasis, $10^{\text {th }}$ Edition, Prentice Hall, Upper Saddle River, New Jersey.

Huang, G. and Song, F.M. (2006). The Determinants of Capital Structure: Evidence From China, China Economic Review, V.17, N.1, pp. 1436.

Im, K.S., Pesaran, M.H. and Shin, Y. (1997). Testing for Unit Roots in Heterogeneous Panels, Unpublished Manuscript, University of Cambridge, Department of Applied Economics.

Im, K.S., Pesaran, M.H. and Shin, Y. (2003). On the Panel Unit Root Tests Using Nonlinear Instrumental Variables, Working Paper, https://papers.ssrn.com/sol3/papers.cfm?abstract_id=482463, pp. 1-14, (Accessed: 05.01.2015).

İzciler, D. (2014). Kurumsal Yönetim İlkelerine Uyum Sürecinin Şirketlerin Performansları Üzerine Etkileri. Yayınlanmamış Yüksek Lisans Tezi, İstanbul: Marmara Üniversitesi Sosyal Bilimler Enstitüsü.

Jensen, M.C. and Meckling, W.H. (1976). Theory of The Firm: Managerial Behavior, Agency Costs and Ownership Structure, Journal of Financial Economics, V.3, N.4, pp. 305-360.

Kakilli-Acaravcı, S., Kandır, S.Y. ve Zelka, A. (2015). Kurumsal Yönetimin BIST Şirketlerinin Performanslarına Etkisinin Araştırılması, Niğde Üniversitesi Iktisadi ve Idari Bilimler Fakültesi Dergisi, C.8, S.1, ss. 171-183.

Kandır, S.Y., Karadeniz, E., Özmen, M. ve Önal, Y.B. (2008). Türk Turizm Sektöründe Büyüme Göstergelerinin Turizm İşletmelerinin Finansal Performansına Etkisinin İncelenmesi, Dokuz Eylül Üniversitesi Sosyal Bilimler Enstitüsü Dergisi, C.10, S.1, ss. $211-237$. 
Kaufman, P. and Watstein, S.B. (2008). Library Value (Return On Investment, ROI) And the Challenge of Placing A Value on Public Services, Reference Services Review, V.36, N.3, pp. 226-231.

Kıyılar, M. ve Belen, M. (2005). Kurumsal Yönetim Kavramı ve İlkeleri: Bir Kurumsal Yönetim Formu Olarak Türkiye'de Holding Yapılanma Biçimlerinin Değerlendirilmesi, isMMMO 1. Uluslararası Muhasebe Denetimi ve VII. Türkiye Muhasebe Denetimi Sempozyumu, Genel Oturum I, Antalya/Belek/Türkiye, 20-24 Nisan, ss. 89-121.

King, M.R. and Santor, E. (2008). Family Values: Ownership Structure, Performance and Capital Structure of Canadian Firms, Journal of Banking \& Finance, V.32, N.11, pp. 2423-2432.

Kumar, J. (2006). Debt vs. Equity: Role of Corporate Governance, $8^{\text {th }}$ Capital Markets Conference (2005), Indian Institute of Capital Markets Paper, Mumbai/India, https://ssrn.com/abstract=592521, pp. 1-19, (Accessed: 26.10.2016).

Külter, B. ve Demirgüneş, K. (2007). Perakendeci Firmalarda Karlılığı Etkileyen Değişkenler: Hisse Senetleri iMKB'de İşlem Gören Perakendeci Firmalar Üzerinde Ampirik Bir Çalışma, Çukurova Üniversitesi Sosyal Bilimler Enstitüsü Dergisi, C.16, S.1, ss. 445-460.

Kyriazis, D. and Anastassis, C. (2007). The Validity of the Economic Value Added Approach: An Empirical Application, European Financial Management, 13(1), pp. 71-100.

La Porta, R., Lopez-de-Silanes, F. and Shleifer, A. (1999). Corporate Ownership Around the World, The Journal of Finance, V.54, N.2, pp. 471517.

Levin, A. and Lin, C.F. (1992). Unit Root Test in Panel Data: Asymptotic and Finite-Sample Properties, University of California at San Diego, Department of Economics, Discussion Paper No: 92-93, pp. 1-66.

Levin, A. and Lin, C.F. (1993). Unit Root Tests in Panel Data: New Results, University of California at San Diego, Department of Economics, Discussion Paper No: 93-56.

Levin, A., Lin, C.F. and Chu, C.S.J. (2002). Unit Root Tests in Panel Data: Asymptotic and Finite-Sample Properties, Journal of Econometrics, V.108, N.1, pp. 1-24

Li, K., Yue, H. and Zhao, L. (2009). Ownership, Institutions, And Capital Structure: Evidence from China, Journal of Comparative Economics, V.37, N.3, pp. 471-490.

Livingstone, J.L. and Grossman, T. (2002). The Portable MBA in Finance and Accounting, $3^{\text {rd }}$ Edition, John Wiley \& Sons, Inc, New York.

Maddala, G.S. and Wu, S. (1999). A Comparative Study of Unit Root Tests with Panel Data and A New Simple Test, Oxford Bulletin of Economics and statistics, V.61, N.S1, pp. 631-652.

Majumdar, S.K. (1997). The Impact of Size and Age on Firm-Level Performance: Some Evidence from India, Review of Industrial Organization, V.12, N.2, pp. 231- 241.

Makelainen, E. (1999). Economic Value Added as a Management Tool, Helsinki School of Economics and Business Administration, Working Paper, www.evanomics.com/evastudy.shtml, pp. 1-38 (Accessed: 23.02.2017).

McConnell, J.J. and Servaes, H. (1995). Equity Ownership And The Two Faces Of Debt, Journal of Financial Economics, V.39, N.1, pp. 131157.

McConnell, J.J. and Servaes, H. (1990). Additional Evidence On Equity Ownership And Corporate Value. Journal of Financial Economics, V.27, N.2, pp. 595-612

Mehran, H., Taggart, R.A. and Yermack D. (1999). CEO ownership, leasing and Debt Financing, Financial Management, V.28, N.2, pp. 5-14.

Mirzaei, H. (2012). A Survey On The Relationship Between Ownership Structure and Dividend Policy in Tehran Stock Exchange, International Conference on Management, Applied and Social Sciences, Dubai/BAE, March 24-25, pp. 327-332.

Morck, R., Shleifer, A. and Vishny, R.W. (1988). Management Ownership and Market Valuation: An Empirical Analysis, Journal of Financial Economics, V.20, N.January-March, pp. 293-315.

Morck, R.K., Stangeland, D.A. and Yeung, B. (1998). Inherited Wealth, Corporate Control and Economic Growth: The Canadian Disease, National Bureau of Economic Research Working Paper Series, Working Paper, No.6814, https://www.nber.org/papers/w6814.pdf, pp. 1-68, (Accessed: 09.01.2015).

Müslümov, A. (2005). The Financial and Operating Performance of Privatized Companies in the Turkish Cement Industry, METU Studies in Development, V.32, N.1, pp. 59-101.

Nazir, M.S. and Afza, T. (2009). Impact of Aggressive Working Capital Management Policy on Firms' Profitability, The IUP Journal of Applied Finance, V.15, N.8, pp. 19-30.

Oruç, E. 2012). Temsil Teorisi Çerçevesinde Sahiplik Yapısının İşletmelerin Finansal Kararları Üzerine Etkisi: iMKB Uygulaması. Yayınlanmamış Doktora Tezi, Antalya: Akdeniz Üniversitesi Sosyal Bilimler Enstitüsü.

Palepu, K.G., Healy, P.M. and Bernard, V.L. (2000). Business Analysis and Valuation, $2^{\text {nd }}$ Edition, South-Western College Publishing, Cincinnati. 
Pavelkova, D. and Knapkova A. (2003). Factors Influencing Economic Value Added in The Selected Sector of The Industry, The Seventh International Conference on Global Business and Economic Development, Bangkok/Thailand, 8-11 January, pp. 1210-1221

Pedersen, T. and Thomsen, S. (1997). European Patterns of Corporate Ownership: A Twelve-Country Study, Journal of International Business Studies, V.28, N.4, pp. 759-778.

Pushner, G.M. (1995). Equity Ownership Structure, Leverage, And Productivity: Empirical Evidence From Japan, Pacific-Basin Finance Journal, V.3, N.2-3, pp. 241-255.

Rakshit, D. (2006). EVA Based Performance Measurement: A Case Study of Dabur India Limited, Vidyasagar University Journal of Commerce, V.11, pp. 40-59.

Rappaport, A. (1998). Creating Shareholder Value: A Guide for Managers and Investors, Revised and Updated Editions, The Free Press A Division of Simon \& Schuster, New York.

Sağlamer, E. (2003). Dolaylı Yabancı Sermaye Yatırımları ve Dış Yatırımcıların Türk Sermaye Piyasasına Çekilmesi. Yayınlanmamış Yüksek Lisans Tezi, İzmir: Dokuz Eylül Üniversitesi Sosyal Bilimler Enstitüsü.

Saldanlı, A. (2006). Geleneksel ve Değer Bazlı Finansal Performans Ölçüm Yöntemlerinin İncelenmesi ve Ekonomik Katma Değer Analizi. Yayınlanmamış Yüksek Lisans Tezi, İstanbul: İstanbul Üniversitesi Sosyal Bilimler Enstitüsü.

Sayman, Y. (2012). Sahiplik Yapısının Firma Performansı ve Sermaye Yapısı Üzerine Etkileri: íMKB’de İşlem Gören Üretim Firmalarında Bir Uygulama. Yayınlanmamış Doktora Tezi, Ankara: Ankara Üniversitesi Sosyal Bilimler Enstitüsü.

Singh, J.P. and Pandey, S. (2008). Impact of Working Capital Management in the Profitability of Hindalco Industries Limited, The ICFAI Journal of Financial Economics, V.6, N.4, pp. 62-72.

Toraman, C. ve Okuyan, H.A. (2009). İşletmelerde Ortaklık Yapısında Yoğunlaşmanın Kaynak Yapısı Üzerindeki Etkisi: İMKB Şirketleri Üzerine Bir Uygulama, Muhasebe ve Finansman Dergisi, C.41, ss. 72-81.

Turaboğlu, T.T. (2002). Vekâlet Teorisi: Firma Sahiplik Yapısı ve Performans İlişkisi Türkiye Uygulaması. Yayınlanmamış Doktora Tezi, Adana: Çukurova Üniversitesi Sosyal Bilimler Enstitüsü.

Ünlü, U., Bayrakdaroğlu, A. ve Şamiloğlu, F. (2011). Yönetici Sahipliği ve Firma Değeri: İMKB için Ampirik Bir Uygulama, Ankara Üniversitesi SBF Dergisi, C.66, S.2, ss. 201- 214.

Villalonga, B. and Amit, R. (2006). How Do Family Ownership, Control and Management Affect Firm Value?, Journal of Financial Economics, V.80, N.2, pp. 385-417

Whittington, G. (1980). The Profitability and Size of United Kingdom Companies, 1960-74, The Journal of Industrial Economics, V.28, N.4, pp. 335-352.

Wooldridge, J.M. (2010). Econometric Analysis of Cross Section and Panel Data, $2^{\text {nd }}$ Edition, The MIT Press, Massachusetts.

Yavan, N. (2006). Türkiye'de Doğrudan Yabancı Yatırımların Lokasyon Seçimi Üzerine Uygulamalı Bir Araştırma. Yayınlanmamış Doktora Tezi, Ankara: Ankara Üniversitesi Sosyal Bilimler Enstitüsü.

Yayla, M., Kaya, Y.T. ve Ekmen, İ. (2005). Bankacılık Sektöründe Yabancı Girişi: Küresel Gelişmeler ve Türkiye, Bankacılık Düzenleme ve Denetleme Kurulu, ARD Çalışma Raporları, Yayın No.6, https://www.bddk.org.tr/websitesi/turkce/Raporlar/Calisma_Raporlari/130120056.pdf, ss. 1-41, (Erişim Tarihi: 07.12.2016).

Young, S.D. and O'Byrne, S.F. (2001). EVA and Value-Based Management: A Practical Guide to Implementation, McGraw-Hill, New York.

Yurtoglu, B.B. (2000). Ownership, Control and Performance of Turkish Listed Firms, https://papers.ssrn.com/sol3/papers.cfm?abstract_id=2061297, pp. 193-222, (Accessed: 09.12.2016).

Zhang, G. (1998). Ownership Concentration, Risk Aversion And The Effect Of Financial Structure On Investment Decisions, European Economic Review, V.42, N.9, pp. 1751-1778. 